\title{
RESPONSIBILITY OF MEMBERS OF THE BODY WHICH EXECUTES BUDGET OR THE FINANCIAL PLAN FOR VIOLATING THE DISCIPLINE OF PUBLIC FINANCE
}

The Act on the Responsibility for Violating the Discipline of Public Finances, ${ }^{1}$ which has been in effect for over three years is to regulate, as suggested by the legislator, in a comprehensive and complex way, the subjective and objective scope of a particular type of legal responsibility which is the responsibility for violating the discipline of public finances. One of the major changes regarding the current legal state, introduced by this Act to the system of Polish public finances is including the responsibility of the members of executive bodies of collegial character in the responsibility for violating the discipline of public finances. The subject of this report is the legal analysis of the article which allows executing the responsibility for violating the financial discipline from members of such bodies and ratio legis of the implementation of this regulation.

The subjective scope of responsibility is determined by art. 4 . The structure of the responsibility of people who are members of the body which executes budget or financial plan of the unit in the sector of public finances or a unit which is not numbered among the sector of public finances but which receives public resources or which manages the property of these units, was neither included in the Public Finances Act of 1998, nor by the regulations which concern the financial discipline that had previously been in effect ${ }^{2}$. The Public Finances Act of 1998 restricted the

1 Act of $17^{\text {th }}$ December 2004 on responsibility for violating the discipline of public finances (Journal of Laws of 2005. No 14, pos. 114 with further changes, referred to as „a. a. v.d.o.p.f.”), that came into effect on July $1^{\text {st }}$ 2005.

2 Before the act on responsibility for violating the discipline of public finances came into effect this issue had been regulated with an Act of November 26 th 1998 about public finances. The Act concerning public finances of 1998 devoted to the problem of the discipline of public finances only a few regulations. The major part of regulations, both from the range of the material law as well as the procedural law was spread among a few legal acts of a different degree, that is in the Act of May $20^{\text {th }} 1971$ - The Code of Criminal Procedure.) (regulations mentioned in art .170 u.f.p. of 1998 r. in con. with art. $3 \S 2$ of act of August $24^{\text {th }} 2001$ r. - Regulations which introduced the code of criminal procedure (Journal of Laws No 106, pos. 1149 with further changes), act of May $20^{\text {th }} 1971$ - Code of Offences (Journal of Laws No 12 pos. 114 with further changes.), regulations mentioned in art. 142 u.f.p. of 1998.), the ordinance of the Council of Ministers of April $27^{\text {th }} 1999$ concerning the characteristic features of procedure of appointing the spokesmen of the discipline of public finances, decision-making bodies as well 
scope of subjective responsibility for violating the discipline to employees at the unit in the sector of public finances and other people who administered public resources (art. 137 of Act of Public Finances of 1998) . $^{3}$

To justify the necessity to extend, in comparison with the solutions which were previously valid, the scope of subjective responsibility for violating the financial discipline over the people who were the members of the body that executed the budget or financial plan of a given unit or the manager of its property, during works on the act, it was emphasized that the need to extend the responsibility was indicated many times, among other things, on account of wide decisive powers, which collegial bodies had at their disposal in some special funds or units of the local government on county and provincial level ${ }^{4}$. The lack of the responsibility of the members of collegial bodies in case of passing resolutions that included an authorization or an order to perform an action which violated the discipline of public finances, resulted in the impunity of both executors of the resolution who directly performed it and its authors. Before the regulation commented on came into effect it was impossible to include people who were the members of collegial bodies into responsibility for violating the discipline of public finances. In the ruling of 13 March 2003 the Main Adjudication Commission admitted that the management could not be responsible for violating the financial discipline. On the other hand, the member of the management, who contributed to some particular decisions by the management (concerning giving a grant), couldn't have made this decision by himself, because it was a collective decision, made by a group of people in a legally specified procedure ${ }^{5}$. In the assessment of the legislator, this regulation allows the possibility to be held responsible by the members of collegial bodies as perpetrators who ordered to commit an action which violates the discipline of public finances. In this way the responsibility is individualized.

Involving the people who are members of the body which executes budget or a financial plan in the responsibility for violating the discipline of public finances is implemented by means of a legal fiction specified in the art. 20 of v.d.o.p.f Act.

as detailed rules of procedures concerning violation of the discipline of public finances (Journal of Laws No 42 pos. 421 with further changes.), in the Minister of Finance's ordinance of August $4^{\text {th }} 1999$ concerning the work of decision-making commissions and spokesmen of the discipline of public finances (Journal of Laws No 69, pos. 765) the ordinance of the Council of Ministers of December $14^{\text {th }} 1999$ about detailed rules and procedures of performing punishment concerning ban on performing administrative functions connected with having public resources at disposal. (Journal of Laws No 106, pos. 1206).

3 In the doctrine of administrative law, collegiality constitutes the way of acting of a collective body. (tres faciunt collegium). From a functional perspective the collegiality means the procedure of acting and deciding which relies on examining cases that belong to the competence of a given authority, often by majority of votes. From a structural perspective the collegiality indicates the way of organization of a given organ. The whole team is authorized to act (if quorum meets), and not particular people who are the members of the body. See: Wielka encyklopedia prawa, red. E. Smoktunowicz, C. Kosikowski, Warsaw 2000, p. 346.

4 From the justification of the governmental project of the Act on responsibility for violating the discipline of public finances, parliamentary form no 1958.

5 DF/GKO/Odw.-136/173/2002, Lex nr 81679. 
The member of an executive collegial body, participating in the process of passing a resolution which contains an order or an authorization to commit an action that violates the discipline of public finances is responsible for the aforesaid action, if the person had not raised an objection to this resolution. According to the rules specified in art. 20 of v.d.o.p.f. Act the person is responsible when he jointly meets the following premises:

- is a member of a collegial body which executes budget or a financial plan of the unit of a sector of public finances or a unit which is not numbered among the sector of public finances which receives public resources or which manages the property of these units;

- took part in passing a resolution which contained an order or an authorization to commit an action which violates the discipline of public finances;

- did not raise an objection to this resolution in a written form or verbally to protocol, or did not vote against the resolution in the case of a vote by rollcall.

Responsibility for violating the discipline of public finances has, according to general rule, a strictly individual character and the article which enforces the responsibility from a person who takes part in passing a resolution theoretically does not modify this rule. Still, the responsibility is held by particular individual people and not by bodies. In the situation when violation of financial discipline occurs as a result of a collegial body's action it does not settle this responsibility in gremio $^{6}$.

However, the structure of responsibility which is based on an assumption that the act of voting to accept this resolution is identical with making an order to perform this resolution, is open to doubts of legal nature. In the literature in this field, it is argued that it is difficult to accept the application of the repressive law towards the people to whom the committment of an offence is ascribed on the grounds of the legal fiction ${ }^{7}$. Moreover, interpreting it ad absurdum, it is easy to imagine a situation when the members of a collegial body pass unanimously some resolution, and then raise objection in a written form in order to free themselves from any probable responsibility ${ }^{8}$.

6 L. Lipiec-Warzecha, Ustawa o odpowiedzialności za naruszenie dyscypliny finansów publicznych. Komentarz, Warsaw 2008 (in print).

7 „With absolute certainty, voting on a resolution is not equivalent to the action of a collegial body, and for sure one cannot recognize that it is identical with giving any order" - Ustawa o finansach publicznych. Ustawa prawo zamówień publicznych: P. Kryczko, Cracow 2005, p. 15.

8 In consequence people who created specific actions, then negate them in fear of being accused of violating the discipline of public finances. P. Sławiszyn, Zmiany w odpowiedzialności za naruszenie dyscypliny finansów publicznych jako przykład sanacji finansów publicznych w Polsce, (w:) Ogólnopolska Konferencja Naukowa Sanacja finansów publicznych w Polsce. Aspekty prawne i ekonomiczne, red. K. Święch, A. Zalcewicz, Szczecin 2005, p. 380. 
In the light of the above-mentioned case, the aim of the regulation, that is to determine which people are responsible for making decisions is not possible to be achieved ${ }^{9}$. The open nature of the ballot does not provide the answer to a question in what way a given person was voting. This condition would be only fulfilled if the open vote by roll-call was implemented ${ }^{10}$.

During the progress of works on the regulation in question it was mentioned that the intention of "constitution of the responsibility for the discipline of public finances of people who are members of collegial bodies and who have at their disposal public resources is understandable. Bodies of legal persons accepted to the sector of public finances have at their disposal huge public resources and they distribute them not always in a legal way. Solutions suggested in this subject, however, (especially art. 20 and 29 of Reg. 2 of v.d.o.p.f.) are hard to be recognized as right. They are incoherent with rules which regulate legal persons' functioning. The proposed solution requires consultation with the experts who specialize in civil and administrative law, above all in the range of the possibilities of ascribing the legal responsibility to the members of the body for a decision (resolution) of this body, as well as possibilities to recognize the resolution of the body as an "order" to perform an action which violates the discipline of public finances, or more precisely, the lack of opposition to such a resolution as an order to perform a criminal act (art. 20 of Reg. 1 of v.d.o.p.f.). Here, it is also worth emphasizing the fact that the responsibility for violating the discipline of public finances can be held by a person who committed an offensive act (art. 19 of Reg.1 of v.d.o.p.f.) or gave an order to perform such an act (art. 19 of Reg. 3 of v.d.o.p.f.). The member of a collegial organ, even if he votes for passing a resolution, which could result in violating the discipline, personally neither commits an offensive act nor gives an order to commit such an act. He just contributes to the fact of violating the discipline by the body. However, it is also difficult to judge whether he co-operates with the others in the process of violation, and such a form of violation does not result in liability for it because the regulation does not envisage such a possibility"11.

9 From the justification of the governmental project of the Act on responsibility for violating the discipline of public finances, parliamentary form no 1958, p. 2.

10 E. Ruśkowski, J. M. Salachna, Wpływ zmian regulacji zasad publicznej gospodarki finansowej na odpowiedzialność za naruszenie dyscypliny finansów publicznych, „Finanse Komunalne” 2006, no 10.

11 "The scope of responsibility of people who pass a resolution and perform it was ambiguously settled in the project too. If even it is assumed, in accordance with art. 19 Of Reg. 1 and 3, that is such situation they both are responsible, but doubts appear in relation to article 29 Reg 2. From it results that, only when the one who performs the resolution frees himself from responsibility, the members of the body who passed this resolution, and not all of them, but only the ones who have signed the written conformation of performing the resolution. However, when there is no such document, the responsibility rests on each member of the body that took part in passing the resolution who did not raised an objection to the resolution and voted for it. I am leaving the fact that in the presence of the latitude in the form of written confirmation of performing a resolution and the lack of an obligation to sign it by all who had voted on it, it is however difficult to receive such document. Doubtful is also the institution of raising an objection to the resolution. Towards the lack of regulations in other legal acts this situation will have only one result: the member of a collegial body who raises an objection is free from responsibility for the decision of the whole body. Objection will have no influence on the importance of the resolution and obligation to 
Beyond the range of hypothesis of art. 4 point 1 of v.d.o.p.f. are councilors who, being members of a decision-making body, and not an executive body, and borough leaders (mayors, presidents), who are not a collegial body. They are the managers of budgetary units, but the regulations (decisions) are taken as the communities' executive bodies, not as people who only manage the Municipal Council. In the literature in this field, it is emphasized, that they are the managers of a unit of the public finances' sector (art. 4 point 2 of v.d.o.p.f.), however decisions concerning management of public resources are made by them as executive bodies of a community, and not by people who lead an office ${ }^{12}$.

The next problem connected with practical application of the responsibility of collegial members of executive bodies is the possibility (or rather impossibility) to specify the level of the offence of individual people who took part in the act of passing the resolution that included an order or an authorization to commit a crime which violated the discipline of public finances. Ascribing responsibility to people covered under hypothesis art. 4 point 1 can be difficult because of the necessity to prove them an intentional or non-intentional character of their action. Responsibility for violating the discipline of public finances is held by a person to whom the guilt can be attributed to during the time of committing the violation (art. 19 of Reg. 2 of v.d.o.p.f.). The guilt constitutes the subjective basis of responsibility. The guilt is when the perpetrator of the violation can be accused of committing a punishable offence, but the accusation must be based on a possibility to believe in a legal norm ${ }^{13}$.

We can speak about a violation of the financial discipline committed by a member of a collegial organ that implements the budget, also when it is possible to charge the perpetrator with the fact that he did not believe in the legal norm which specified the rules of public resource management, despite the fact that in concreto he had a possibility to act according to the norm. Determining the way of understanding in the process of proving the culpable act the Main Adjudication Commission in justification of one of the legal decision has made a reasoning from which it can be concluded that "fundamental meaning for the substantive correctness of the adjudication will have an answer to a question: whether the Accused in the subjective real state had the possibility to behave in a different way? In other words one should indicate the Accused how she should have behaved in order not to violate the discipline of public finances. If, however, it is revealed that in a given

perform it. When the regulations have such a form is hard here to believe that the members of collegial bodies who voted for passing a resolution would behave otherwise than raise an objection to it just after they had passed it, and what in fact would free them from responsibility, and would not influence the content of the resolution" (M. Karlikowska, Commissioned opinion of the Studies and Expertises Office of the Seym of the Republic of Poland about the governmental project of an Act about the responsibility for violating the discipline of public finances, parliamentary form no 1958, www.sejm.gov.pl).

12 E. Ruśkowski, J.M. Salachna, Wpływ zmian regulacji zasad publicznej gospodarki finansowej, p. 7.

13 L. Gardocki, Prawo karne, Warsaw 1999, p. 51; K. Buchała, A. Zoll, Kodeks karny. Część ogólna. Komentarz do art. 1-116 Kodeksu karnego, Cracow 2000, p. 24. 
circumstances the accused had no other possibility to behave, despite an impartial ascertainment that a penal act had been committed, guilt cannot be attributed to her"14. To attribute responsibility it is enough to indicate a formal violation of the rules of law, but offence must be proved being the perpetrator's guilt. (decision of MAC of $23^{\text {rd }}$ November 2006 r., DF/GKO-4900-83/103/06/2564, non publ. $)^{15}$. In the interpretation of art. 4 point 1 , there appear some doubts concerning how one can attribute guilt to a member of a body who took part in voting for a resolution (as a result of which the discipline has been violated), in a situation when it is only known that he did not raise an objection to this act ${ }^{16}$

With the individualization of the responsibility for violating the discipline of public finances the problem of the sentence, except just premises, is connected. In the process of inflicting a punishment the regulations demand, inter alia, to take into consideration also motives and the way of acting, personal conditions of the perpetrator, his professional experience, the way he carries out his business responsibilities, conduct after he violated the discipline. Moreover, the extenuations, which exemplary catalogue is formed by article art. 36 of Reg. 2, that allow to use the benefits of an exceptional commutation of punishment, or refrain from imposing the punishment, concern strictly personal circumstances. ${ }^{17}$. In this context, respected rules of the individualization of the responsibility expressed in art. 33 of Reg. 3 of v.d.o.p.f., which imposes the consideration of all circumstances that may influence the infliction of the punishment only to the person to whom it is concerned, are impossible.

Problematic can be also interrelation between the act of voting with giving an order and determining whether the fault of the member of a collegial body should be examined with respect to the act voting itself or to giving an order. It often occurs that the resolution passed by the management does not constitute any order (e.g. resolution about a change of financial plan, in a situation when the change is not acceptable constitutes violation of the discipline of public finances, despite the fact that it is not an order to commit a penal act) ${ }^{18}$.

GKO statement of September 2002, DF/GKO/Odw.-94/126-RN-29/2002, LEX no 79999. 15 The opinion of the NSA expressed under the government of Budgetary law which was in effect until December exemplified by his behaviour premises of violating the budgetary discipline [currently: discipline of public finances - L.L.W.], but to whom guilt cannot be ascribed to" (verdict of NSA of January $8^{\text {th }} 2002$ r., III SA 2079/01, nonpubl.).

16 E. Ruśkowski, J.M. Salachna, Wpływ zmian regulacji zasad publicznej gospodarki finansowej, p. 7.

17 As the extenuations one particularly can take into account: acting or renunciation on specific motives or in specific conditions, that must be taken into account, in order to prevent the damage of public property, being distinguished before violating the discipline of public finances by an excellent attitude towards fulfilling his professional duties, contribution to remove the harmful consequences of violating the discipline of public finances or making efforts to achieve it.

18 P. Kryczko, Wybrane zagadnienia z zakresu podmiotowego i przedmiotowego odpowiedzialności za naruszenie dyscypliny finansów publicznych w orzecznictwie Głównej Komisji Orzekającej, (w:) Gospodarka budżetowa jednostek samorządu terytorialnego, red. W. Miemiec, Wrocław 2006, p. 336-337. 


\section{Conclusions}

The need to spread the responsibility for violating the discipline of public finances over members of collegial bodies who perform budget or a financial plan has been indicated many times, among other things, on account of wide decisive powers, which collegial bodies have at their disposal in some special funds or units of the local government on county and provincial level.

Specifying a separate categories bearing responsible, that are members of collegial body, there were not dissipate doubts which previously existed in the doctrine, administrative and judicial case-law administrative judicature; currently the doubts especially concern proving that particular individuals committed an offensive act, conditions on which the responsibility may be laid upon them.

Doubts of a legal nature are raised in reference to the scope of responsibility members of collegial bodies. Voting for a resolution (or against it) cannot be identified with committing an offence or with giving an order to commit such an act. 


\section{Streszczenie}

Ustawa z dnia 17 grudnia 2004 roku o odpowiedzialności za naruszenie dyscypliny finansów publicznych, która obowiązuje już od ponad trzech lat, reguluje - jak sugeruje ustawodawca - zupełnie i kompleksowo podmiotowy oraz przedmiotowy zakres szczególnego rodzaju odpowiedzialności prawnej jaką jest odpowiedzialność za naruszenie dyscypliny finansów publicznych. Jedną z kluczowych instytucji wprowadzoną przez ustawę do polskiego systemu finansów publicznych, jest ustanowienie odpowiedzialności członków organów wykonawczych o kolegialnym charakterze. Przedmiotem niniejszego referatu jest analiza prawna przepisu, który reguluje taką odpowiedzialność oraz jego ratio legis. 